臨床 ヘパリン静注後血浆リパーゼとカイロミクロンとの

反応異常がみられた高中性脂肪血症の 1 例

千葉大学医学部第二内科

平良 真人 白井 厚治〉 森崎 信尋

斎藤康 熊谷朗

川鉄健保千葉病院内科松岡，信夫

千葉市立病院外科 上村 重明

\title{
HYPERTRIGLYCERIDEMIA (TYPE V) ASSOCIATED WITH IMPAIRED INTERACTION OF POST HEPARIN PLASMA LIPASE WITH CHYLOMICRONS
}

Masato TAIRA, MD, Kohji Shirai, MD, Nobuhiro MorisaKI, MD,

Yasushi SAITO, MD and Akira KUMAGAI, MD

The Second Department of Internal Medicine, School of Medicine Chiba University

Nobuo MATUSUOKA, MD

Kawatetsu General Hospital, Chiba

Shigeaki UemuRA, MD

Chiba City Hospital, Chiba

\begin{abstract}
概要 妊娠中に高度の中性脂肪血症をきたし，膵炎を合併し流産に至つた28才，女性につきり ポ蛋白画分の性状，へペリン静注後血浆リパーゼ活性，更にエストロシェン負荷試験を行ない， 若干の知見を得たので報告する。リポ蛋白分画では，カイロミクロンと超低比重リポ蛋白の増 加がみられ，高脂血症 V 型を呈した。カイロミクロンの脂質組成は变化なかつたが，巨大なカ イロミクロンの存在が欢られた。精製牛ミルクリポ蛋白リバーゼによる患者のカイロミクロン 中性脂肪分解は，正常者のカイロミクロンと差がみられなかつた，へパリン静注後血浆中には， 基質としてTriton-X100で乳化したトりオレインを用いると，リポ蛋白リバーゼ活性と肝性り パーゼ活性は共に存在することが認められた。一方基質としてカイロミクロンを用いると，患 者へパリン静注後血浆リパーゼ活性は，正常者のそれの11\%しかみられなかつた。これらのこ とは本患者のへパリン静注後血㓡リパーゼとカイロミクロンとの反応様式に異常のあることを 推測された。更にエストロジェン(プレマリン $11.25 \mathrm{mg} /$ 日× 2 日)を負荷すると，血中中性脂 肪値は, $600 \mathrm{mg} / \mathrm{dl} か ら 1200 \mathrm{mg} / \mathrm{dl}$ と急上昇を示した。一方，脂肪制限食摄取後，血中中性脂肪 值が $300 \mathrm{mg} / \mathrm{dl}$ に低下したとき，プレマリン $11.25 \mathrm{mg} /$ 日 $\times 6$ 日を負荷しても中性脂肪值は上昇 がみられなかつた。これらのことから高中性脂肪血症そのものが，エストロジェンによる血中 中性脂肪上昇作用を助長している可能性が推測された。
\end{abstract}

緒言

高中性脂肪血症は, 黄色腫, 脇炎を伴うことが 知られ1),その原因としては,リポ蛋白リパーゼの

[昭和57年 7 月 12 日受稿〕
醅素欠損症(Type I ) ${ }^{12}$, 活性化因子であるアポリ ポ蛋白C-IIの欠損症等 ${ }^{23)}$ が明らかにされてきた。 しかしカイロミクロンを伴う高中性脂肪血症 (Type V)はいまだその詳細な解明はなされてお らず，肝での合成元進4)扰よ゙゙リポ蛋白リパーゼ 
の機能低下5代推測されているが，その詳細は明 らかにされていない.今回我々は妊娠中に高度の 中性脂肪血症 (Type V)をきたし，膵炎を併発し， 流産に至つた28才，女性のリ术蛋白分析，人ハリ ン静注後血禁りパーゼ活性の倹討，更にエストロ ジェン負荷試験を行ない，本症の病因について検 討を加え，若干の知見を得たので報告する。

\section{症例}

患者：28才，女性。

主訴：左上腹部痛，乳び血清.

家族歴：両親，同胞に同様の症状を有する のは見られない。

既往歴：（1）23才のとき, 呕吐を伴ら左側腹 部から下腹部にかけて痛みあり。某病院に入院し た、産婦人科的な異常所見はなかつたが，ダグラ ス穿刺にて黄色透明な液が採取された。このとき 強度の乳び血清がみられ，血中中性脂肪値は1830

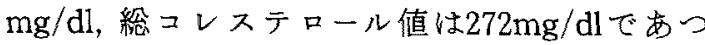
た，血清アミラーゼ，尿中アミラーゼは正常であ つた。入院後 1 週間で中性脂肪值は $336 \mathrm{mg} / \mathrm{dl}$, 総 コレステロール值は $114 \mathrm{mg} / \mathrm{dl}$ あ゙低下し，症状水 消失した（2）24才のとき，妊娠 6 力月目で死産。 胎児は発育不良であつた。血清脂質等の詳細は不 明。

現病歴：昭和56年，妊娠6,8,9力月目に呕吐 を伴ら左上腹部执よび背部の疼痛発作を起こし た，血中和よび尿中アミラーゼが高値であつたこ とから，急性膵炎と診断された。その際強度の乳 び血清を指摘された，2回目の腹痛発作時，血中 中性脂肪值は $1500 \mathrm{mg} / \mathrm{dl}$ と上昇がみられ，さらに 3 回目の腹痛発作時に中性脂肪值は $5500 \mathrm{mg} / \mathrm{dl}$ ま で上胼が文られた。この3回目の腹痛発作の翌日， 胎児は死亡，死産となつた，胎児は体重 $1330 \mathrm{~g}$, 身 長 $41 \mathrm{~cm}$ で発育不良。胎盤には一部organizationを 伴ら ischemic necrosisがあつた，死産した 1 週間 後には中性脂肪値は700 $\mathrm{mg} / \mathrm{dl}$ で低下した（図 1). 強度乳び血清の原因精査のため昭和 56 年 6 月当科入院となつた。

入院時現症：身長 $156 \mathrm{~cm}$, 体重 $56 \mathrm{~kg}$ ，発育良 好, 体温 $36.8^{\circ} \mathrm{C}$, 血圧 $120 / 60 \mathrm{mmHg}$, 脈拍 $78 /$ 分整,

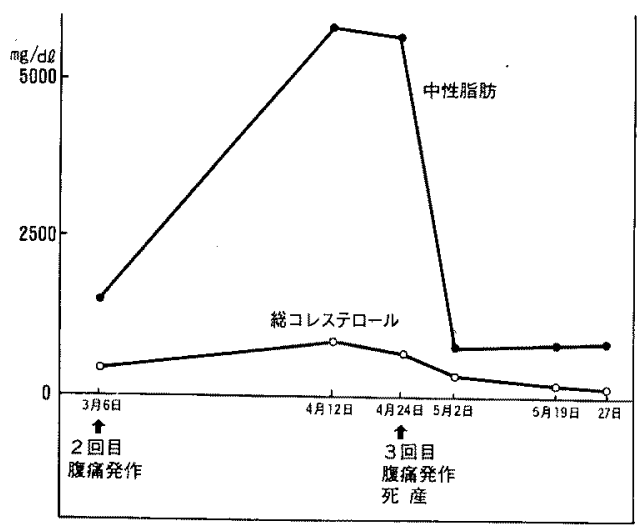

図 1，娃娠の経過と血中脂質の変動

皮䖉に黄色腫，発瘆，皮下結節は見られなからた。 眼䀫結膜の荅白, 眼球結膜の黄染を認めず，角膜 リングるみられなかつた，腹部に腫瘤は触知せず， 怪骨前部の浮腫なく，神経学的異常所見は認めら れなかつた。

入院時一般検査成績：入院時の一般検査成績 を表 1に示した，血液化学では，中性脂肪值は441 $\mathrm{mg} / \mathrm{dl}$ と高值を示し，総 レステロール值は106 $\mathrm{mg} / \mathrm{dl}$ と低值を示した他，特に異常を認めなかつ た。血算, 検尿, 血清学的検查, 内分泌学的検查 でも異常がみられなかつた。75g糖負荷試験で耐 糖能の低下がみられた。なお，1325kcal/日の食事 療法にて，2 週間後早朝空腹時血糖値は $100 \mathrm{mg} / \mathrm{dl}$ まで低下した，尿中，血中アミラーゼは正常であ つたが, 膵臟に関泉る検査では腹部CTで膵尾部付 近にlow density areaが認められた（図2），腹部 超音波断層法では，葫尾部と脾門部の間にmass lesionを認めた。逆行性膵胆管造影法では嗒管の 偏位が見られたが,壁に不整虫認められなからた。 これらの所見から，荤尾部の仮性のら胞が形成さ れていることが推測された。腹腔動脈造影では， 脾静脈の閉塞がみられた，荤外分泌機能検查とし て，PFDテストを行な5と，93\%と正常であつた。 これらの所見から，急性膵炎のあつたことが推測 された。

\section{脂質代謝系検查の方法}

\section{1）リポ蛋白分画の脂質組成}

血清 $4 \mathrm{ml} \kappa$ plasma density buffer $(0.9 \%$ 


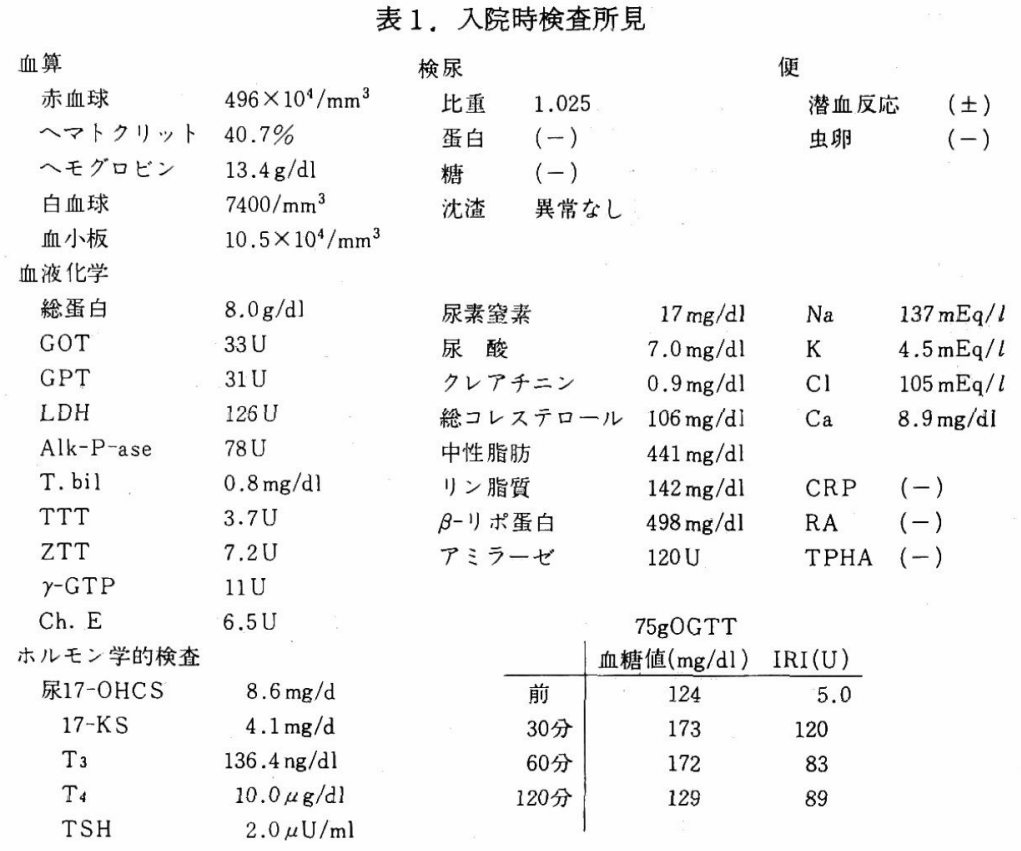

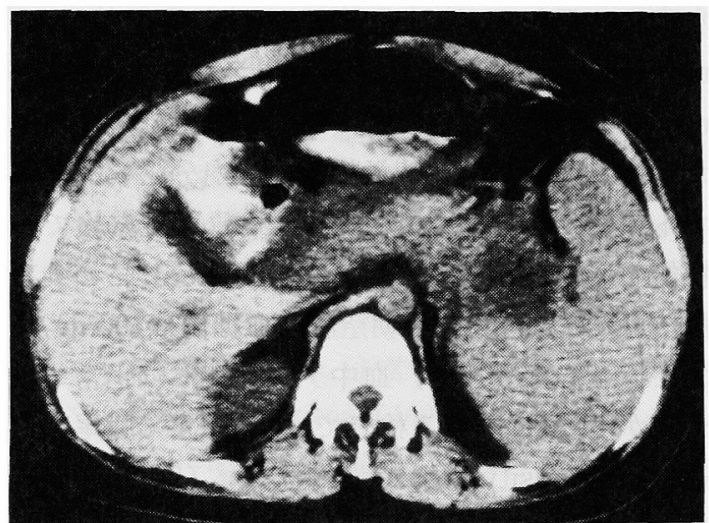

図 2，腹部CT scanning像(第12胸椎中央部横断面). 脇尾部にlow density areaが認められた。

$\mathrm{NaCl}-10 \mathrm{mM}$ tris- $\mathrm{HCl}, 1 \mathrm{mM}$ DETA-0.01\% $\left.\mathrm{NaN}_{3}, \mathrm{pH} 7.4\right) 1 \mathrm{ml}$ 加克, $13000 \times \mathrm{g} 30$ 分, $4{ }^{\circ} \mathrm{C}$ で遠心し，その上層部をカイロミクロンとした。 その下層を $110000 \times \mathrm{g}, 20$ 時間超遠心し，上層を超 低比重》ポ蛋白(VLDL)，その下層にKBrを加兄 て密度（d）1.063に調整し，同様に遠心，更にそ の下層を $\mathrm{d}=1.21$ にして遠心し，それぞれの上層 を低比重リポ蛋白(LDL), 高比重リポ蛋白(HDL)
として分離した，中性脂肪，リン脂質，コレステ ロールは酵素法のキット（中性脂肪はヤトロン社, リン脂質，コレステロールは日本商事）で測定し た.

2) リポ蛋白リパーゼ（LPL)によるカイロミク ロンの水解

LPLは牛スキムミルクから，ヘパリンセファ ロース $4 \mathrm{~B}$ 用いたアフィニティクロマトグラ フィーで精製した6). 比活性は $20 \mathrm{mmol} \mathrm{FFA} / \mathrm{mg}$ 蛋白/hであつた. 対照者のカイロミクロンは, バ ター $50 \mathrm{~g}$ 経口摂取し， 2 時間目血清より調製した。 カイロミクロン中性脂肪分解反応溶液は, カイロ ミクロン(中性脂肪 $0.4 \mathrm{mg}$ ), 脱脂した牛アルブミ ン (BSA) $4 \mathrm{mg}$, ミルクLPL 10ng蛋白, $0.1 \mathrm{M}$ Tris-HCl緩衝液（pH8.6）からなり，最終容量を $0.25 \mathrm{ml}$ とし， $37^{\circ} \mathrm{C} ， 30$ 分間インキュベーションし た後, $100^{\circ} \mathrm{C}, 3$ 分間ボイルして反応停止した後, 遊離した脂肪酸をNEFAキット（日本商事）を用 いて測定した，盲検は，ミルクLPLを加えずに同 様の操作を行なつた。

3）へパリン静注後血浆リパーゼ活性 (PHLA) ノボヘパリン (小玉社製) 10単位/体重kgを生食 
$5 \mathrm{ml}$ と混ぜ静注し，経時的に採血した後，血采を 分離し，それをへパリン静注後血装 (PHP) と乙 た. PHLAはtri $\left[1 .{ }^{14} \mathrm{C}\right]$ oleoyl glycerolを基質と して用い，すでに報告した方法 ${ }^{6} に$ 準じて測定し た。 反応溶液は，最終容量 $250 \mu 1$ 中に, trioleoylglycerol $377 \mathrm{nmoles}$, tri $\left[1 .{ }^{14} \mathrm{C}\right]$ oleoyl glycerol $0.04 \mu \mathrm{Ci}$ (specific actvity $53 \mathrm{mCi} / \mathrm{mmol}$, New England Nuclear) $0.02 \%$ TritonX-100, 脱脂牛 アルブミン $5 \mathrm{mg}$, apolipoprotein C.II $1 \mu \mathrm{g}, 0.1 \mathrm{M}$

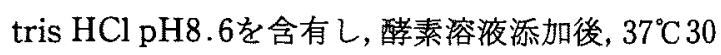
分間インキュベーションした，遊離した $\left[{ }^{14} \mathrm{C}\right]$ oleic acidはBelfrage and Vaughan ${ }^{13)}$ の方法で抽 出，その radio活性を測定した。肝性リパーゼ (HTGL) 活性は，1M NaClを添加して測定した。 LPL活性は，PHLA活性からHTGL活性を引いた ものとした。

\section{4) PHPによるカイロミクロンの水解}

反応溶液はFieldingの方法により ${ }^{7} \operatorname{tri}\left[1{ }^{14} \mathrm{C}\right]$ oleoyl glycerolでラベルされたカイロミクロン (中性脂肪 $=0.25 \mathrm{mg}$ ), BSA $5 \mathrm{mg}, 0.1 \mathrm{M}$ tris- $\mathrm{HCl}$ 緩衝液 ( $\mathrm{pH} 8.6) ， 50 \mu 1$ のPHP (10分後)からなり, 最終容量を $0.25 \mathrm{ml}$ とした. $37^{\circ} \mathrm{C}, 1$ 時間インキュ ベーションした後，先に述べたPHLAの測定と同 様の操作を行ない，遊離した $\left[1-{ }^{14} \mathrm{C}\right]$ oleateの放 射活性を測定した。

\section{脂質代謝系検索の成績}

\section{1）リポ蛋白電気泳動とリポ蛋白分画}

アガロース電気泳動法では, 原点から pre- $\beta$ 分画 にかけて一様の脂質バンドが見られ，カイロミク ロンの存在が推測された. Friedreckson分類では Type Vに属すると思われた，超遠心分離による 分画ではカイロミクロンの存在と超低比重リポ蛋 白画分 $(\mathrm{d}<1.006)$ の中性脂肪の上昇, 低比重り ポ蛋白画分 $(1.006<\mathrm{d}<1.019)$ 乩よび高比重りポ 蛋白画分 $(\mathrm{d}>1.021)$ の総コレステロール，リン 脂質の低下がみられた（表 2)。

2）へパリン静注後血浆リパーゼ活性 (PHLA) ヘパリン静注後血浆リパーゼ活性のうち,リポ 蛋白りパーゼ活性および, 肝性リパーゼ活性とも に，低值ながら正常範丑の活性が認められた（図
表 2, リポ蛋白画分の脂質組成

Mean $\pm S D$

\begin{tabular}{|c|c|c|c|c|}
\hline \multirow[b]{2}{*}{ Chylo. } & \multicolumn{2}{|c|}{$\begin{array}{c}\text { T. Cholesterol } \\
(\mathrm{mg} / \mathrm{d} \|)\end{array}$} & $\begin{array}{l}\text { Triglyceride } \\
(m g / d 1)\end{array}$ & $\begin{array}{l}\text { Phosphol ipid } \\
(\mathrm{mg} / \mathrm{dl})\end{array}$ \\
\hline & 58 & $(0)$ & $447 \quad(0)$ & $68 \quad(0)$ \\
\hline VLDL & 26 & $(23 \pm 10)$ & $179(101 \pm 22)$ & $28 \quad(23 \pm 10)$ \\
\hline LDL & 10 & $(116 \pm 25)$ & $34 \quad(28 \pm 16)$ & $25 \quad(83 \pm 22)$ \\
\hline HDL & 30 & $(52 \pm 11)$ & $28(10 \pm 2)$ & $59 \quad(89 \pm 21)$ \\
\hline Total & 125 & $(791 \pm 11)$ & $688(140 \pm 28)$ & $180(195 \pm 15)$ \\
\hline
\end{tabular}
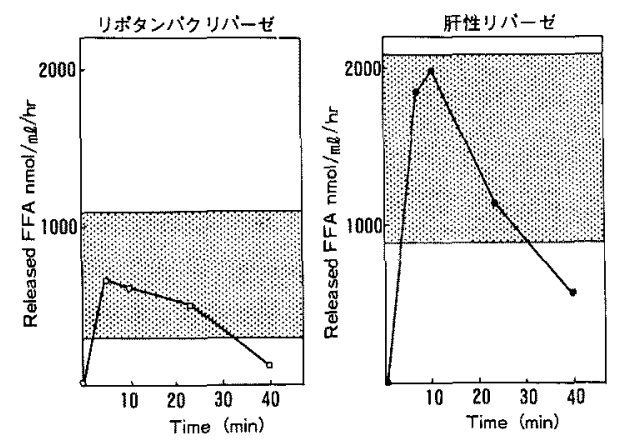

因 3、へパリン静注後血浆リパーゼ活性。点域は正常 域を示す。

3).

3）カイロミクロンの性状

カイロミクロンの脂質組成では，コレステロー ル，中性脂肪，リン脂質とも，対照者のものと有 意の変動は認められなかつた。電䫓像では大小不 同がみられ，特に直径 $5 \mu \mathrm{m}$ 以上の巨大粒子の存 在が認められた(図 4 (1)(2))。精製牛ミルクリポ蛋 白りパーゼによるカイロミクロンの中性脂肪分解 は，正常者のカイロミクロンのものと，有意の差 はみられなかつ（図 4(3)）。

4) PHPによるカイロミクロンの中性脂肪分解 正常人のPHPは，正常人执よび患者のカイロミ クロンの中性脂肪を同程度に水解した，従つてカ イロミクロン中性脂肪の水解されやすさには違い はみられなかつた。しかし患者のPHPは，正常人 および患者のカイロミクロンを共に，正常人の PHPの11\%しか水解しなからた（図 5 ）. 
(1) カイロミクロンの脂筫組成 (重量％)

\begin{tabular}{|c|c|c|c|}
\hline & 総コレステロール & 中性脂眆 & リン脂筧 \\
\hline 患 者 & 11.2 & 70.5 & 18.3 \\
\hline 正常人 & 10.6 & 72.8 & 16.6 \\
\hline
\end{tabular}

(2) カイロミクロンの大きさの分布

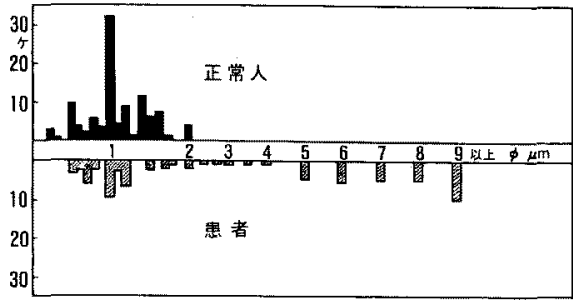

(3) 牛ミルクリボ蛋白リパーセたよるカイロミクロンの水解

\begin{tabular}{|c|c|}
\hline 患者 & 32.6 \\
\hline 正常人 & 29.2 \\
\hline
\end{tabular}

(FFA mEq/mg/hr)

図 4.カイロミクロンの脂質組成と性状, カイロミク ロンの粒子サイズは徳島大学栄養学部 水沼俊美博士 によつて電顕像から計測した。

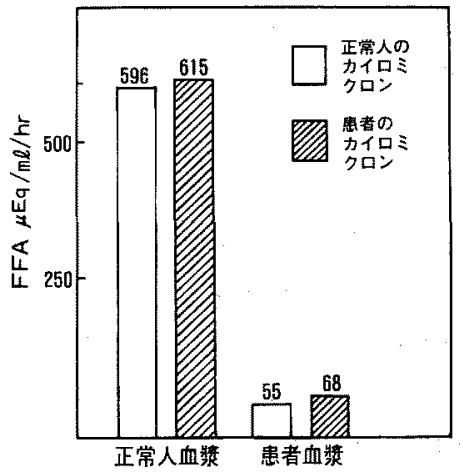

図 5.人ペリン静注後血浆リパーゼによるカイロミク ロンの水解

\section{考案}

本症例は，妊張中以非常な高中性脂助血症をき たし，膵炎を併発し，流産に至つた患者である。 本症例では, Type Vの高脂血症を呈したが, Type Vの高脂血症の原因としては，力イロミクロンの 存在から, 中性脂肪に富さりポ蛋白のクリアラン スの低下が推測されている5). 又肝蔵からのVLDL の過剩分泌によるるのとも言われている゙が，末 だ定説はない、今回，その原因を探るため，リポ

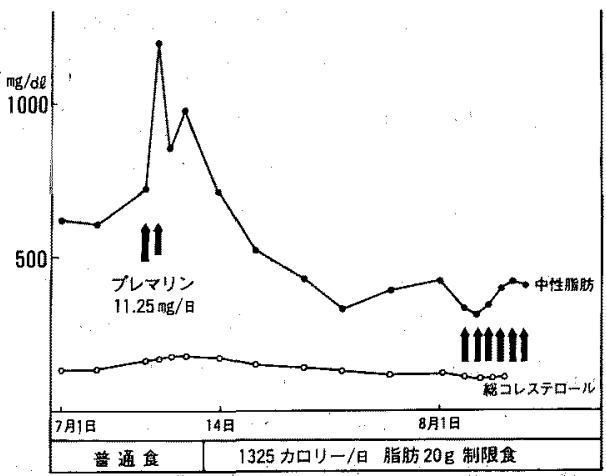

図6，食事療法とブレマリン負荷による血中脂筫の变 動入院後の経過

蛋曰の性状，水解醉素の性嘪，更に妊娠時増悪の 原因としてェストロジェンの影響について検討を 試みた。すず血清脂質の超遠心分画を行なつたと ころ(表 2)，カイロミクロン拉よびVLDL中の中 性脂肪の上昇と, LDLおよびHDLのコレステロー ルの低下が認められた、LDL拈よ゙HDLの一部は VLDL，カイロミクロンの分解によつて産生され ることが推測されている8). 従つて,このリポ蛋白 のパターンからは, カイロミクロンおよびVLDL の分解過程に異常があると推測される。分解過程 の異常の原因としては，基質であるカイロミク口 ン括よびVLDLの異常と, 水解醅素系の機能異常 が考党られる。そこで力イロミクロンの側につい て，脂質組成および性状を調べてみると，総コレ ステロール，中性脂肪およびリン脂質組成には異 常がなからた(図 4(1)).さらにカイロミクロン中 性脂肪の分解されやすさを調べるために，精製し た牛ミルクリポ蛋白リパーゼを用い, 患者のカイ ロミクロン中性脂肪の水解を調べたところ, 正常 人のカイロミクロンと同程度に水解された（図 4 (3)).これらのこと㥙，電影像で大小不同が办られ 異常な巨大粒子がみられたが，基質としては，そ の中性脂肪の分解されやすさといら面からは異常 がないことを思わせる所見である，次に水解酵素 の側から検討を試多た，患者のヘパリン静注後の 血浆は，基質としてはTriton-X100で乳化したト リオレインを用いた場合，リポ蛋白リパーゼ活性 および肝性リパーゼ活性共；正常であつた，従つ 
て，少なくとも酵素が久損している症例とは思わ れなかつた。ここで次に，醅素と基質のインター アクションに異常のある可能性を検討した。すな わち，中性脂肪は水に不溶性のため，水溶液中で は種々のdetergentでエマルジョン化しないと安 定化されない，逆にこのdetergentの種類によつ て，その水解活性が変わつてしまらことが知られ ている9 . 又, 酔素の側も, 基質を認識する際に粒 子の界面と接触する必要があり，その過程で界面 の性状が酵素の機能を左右している可能性があ る。そこで，一パリン静注後血浆の中性脂肪水解 能を生理的な基質であるカイロミクロンを用いて 調ベた。図 5 のごとく，患者のへパリン静注後血 浆は，正常人血浆に上る水解能の約 $11 \%$ しか力1 ロミクロンを分解しなかつた。しかも，正常人の カイロミクロンと患者のカイロミクロンの間に は，水解されやすさに関して有意の差は認めなか つた。 このことはすなわち，酵素と基質とのイン ターアクションに異常があり，アホ犬蛋白等で修飾 されたカイロミクロンとは反応しにくいことを示 唆する成績である。 以上より，中性脂肪分解酵素 とカイロミクロンとの反応に異常があることが, 本症例の高中性脂肪血症の原因の一つとなつてい る可能性が推測された，その精細を明らかにする には，更にリパーゼの活性発現機構の解明が必要 であると思われる。次に，本症例で妊娠中に高中 性脂肪血症をさたした原因を探るために，妊娠時 のホルモンの役割りを調べた。女性ホルモンのう ち, エストロジェンには, 血中中性脂肪を増加さ せる作用があることが知られている(10). そこでエ ストロジェン負荷試験を行なつた。エストロジ ン製剤としてプレマリンを $11.25 \mathrm{mg} /$ 日用いた。 エ ストロシェン負荷試験の結果を図6に示した。血 中中性脂肪值 $600 \mathrm{mg} / \mathrm{dl}$ の時プレマリンを服用す ると，1 日後血中中性脂肪值が $1200 \mathrm{mg} / \mathrm{dl}$ で上 昇した. 次に血中中性脂肪値 $300 \mathrm{mg} / \mathrm{dl}$ の時, プレ マリンを同量服用したところ，6 日間連日服用し ても血中中性脂肪の上萛はみられなかつた。エス トロシェンによる中性脂肪の反応に相異がみられ たことは，血中中性脂肪が高いことが，エストロ
ジェンの血中中性脂肪増加作用を助長している可 能性を示唆しているが，その精細については今後 の検討が必要之思われる。本症例では酎糖能の低 下があり，糖疗病状態が高中性脂肪血症を増覀さ せた可能性むある ${ }^{11}$. 水解醅素系の異常により，中 性脂肪に富もりポ蛋白合成增加に対する適応能が 少ないことが原因となつている可能性もあるが， 今後更に検討を続けていきたい，な拉，現在本患 者は脂肪摂取制限をしつつ外来で経過観察中であ る。

\section{結語}

1）へパリン静注後血浆リパーゼと力イロミク ロンとのインターアタションの異常が一因とな り，水解活性が低下乙，その結果高中性脂肪血症 をきたしたと思われる特異な 1 例を報告した。

2）この患者は，妊娠では高中性脂肪血症を増悪 させた，その一因は，エストロジェンであるらと 推測される。充さ，高中性脂肪血症自身が，エス トロジェンによる血中中性脂肪上昇作用を助長し たものと思われた。

碀辞電子顕销鏡によるリボ蛋白の形態学的模索をして 頂いた德島大学実践栄盖学部 水沼俊美博士に心から感謝 の意を表します。

旭中央病院受診時の所見につき要しては，吉田象二先生 の多大の御助言，御協力を賜り感謝申し上げをす。

\section{文献}

1) Brown WV, et al : Hyperlipidemia, Grune \& Stratton, New York, 1977, p93.

2) Brecknridge WC, et al: Hypertriglyceridemia associated with deficiency of apolipoprotein $\mathrm{C}$ II. New Engl J Med 298: 65, 1978.

3) Yamamura $T$, et al: Familial type I hyperlipoprotenemia caused by apolipoprotein C-II deficiency. Atherosclerosis $34: 53,1979$.

4) Porte D Jr and Bierman EL: The effect of heparin infusion on plasma triglyceride in vivo and in vitro with a method for culculating triglyceride turnover. J Lab Clin Med 73 : 631, 1969.

5) Havel RJ, et al: Splanchnic metabolism of free fatty acids and production of triglyceride of very low density lipoproteins in normolipidemic and hypertriglyceridemic humans. $\mathrm{J}$ Clin Invest $49: 2017,1970$. 
6) Matsuoka $N$, et al: Preparation and properties of immobilized lipoprotein lipase. Biochem Biophys Acta 620:308, 1980.

7) Fielding $\mathrm{CJ}$ : Validation of procedure for exogenous isotopic labeling of lipoprotein triglyceride with radioactive triolein. Biochim Biophys Acta $573: 255,1979$.

8）内藤周幸, 他：リポタンバクの代謝, 内科 49 ： $817,1982$.

9）野間昭夫：動脈壁のリパーゼ。代謝 $17: 17$, 1980.

10) Gluck CJ, et al: Estrogen-induced pan- creatitis in patients with previously covert familial type $\mathrm{V}$ hyperlipoproteinemia. Metabolism 21:657, 1972.

11）村勢敏郎：内科疾患とリポタンパク代謝異常。内 分泌疾患.内科 $49: 871,1982$.

12）竹田亮喛：内料疾患とリボタンパク代謝巽常. 肥 满・糖尿病。内科 $49: 877,1982$.

13) Belfrage $P$ and Vaughan $M$ : Simple liquidliquid partition system for isolation of labeled oleic acid mixture with glycerides. J Lipid Res $10: 361,1969$. 